\title{
RECONSTRUCTION OF GLENOID BONE DEFICIENCY WITH POROUS TITANIUM NICKELIDE IN RECURRENT ANTERIOR SHOULDER INSTABILITY
}

\author{
Valery M. Prokhorenko ${ }^{1}$, Sergey M. Fomenko ${ }^{2}$, Pavel V. Filipenko ${ }^{3 *}$, Petr S. Turkov ${ }^{2}$ \\ ${ }^{1}$ Novosibirsk State Medical University of Public Health, ${ }^{2}$ Novosibirsk Research Institute of Traumatology and \\ Orthopedics of Public Health, ${ }^{3}$ The Sixth Military Hospital of Internal Troops of Internal Affairs Ministry of \\ Russian Federation, Novosibirsk, Russia

\section{ВОССТАНОВЛЕНИЕ КОСТНОГО ДЕФЕКТА ГЛЕНОИДА ПРИ ХРОНИЧЕСКОЙ РЕЦИДИВИРУЮЩЕЙ ПЕРЕДНЕЙ НЕСТАБИЛЬНОСТИ ПЛЕЧЕВОГО СУСТАВА ПОРИСТЫМ НИКЕЛИДОМ ТИТАНА}

\author{
Валерий М. Прохоренко ${ }^{1}$, Сергей М. Фоменко ${ }^{2}$ Павел Вл. Филипенко ${ }^{3 *}$, Петр С. Турков ${ }^{2}$ \\ ${ }^{1}$ ГБОУ ВПО Новосибирский государственный медицинский университет Минздрава России, ${ }^{2}$ ФГБУ \\ Новосибирский НИИ травматологии и ортопедии им Я. Л. Цивьяна Минздрава России, \\ ${ }^{3}$ ФКУЗ 6 военный госпиталь внутренних войск МВД России, г. Новосибирск, Россия
}

\begin{abstract}
INTRODUCTION: One of the main causes of recurrent shoulder instability is a bone defect of the front edge of the glenoid. The available techniques for reconstruction of this bone defect, however, have some disadvantages. OвJестіve: The aim of this study was to develop a new method that can reduce the number of postoperative complications and improve the efficiency of surgical treatment of recurrent anterior shoulder instability with glenoid bone defect. Materials AND methods: We present here a new method for surgical treatment of post-traumatic recurrent anterior shoulder instability with bony defects using porous NiTi. We operated 5 patients using this method. Computed tomography was used in the preoperative preparation of the NiTi graft. The graft was sawed from a cylindrical billet about $1 \mathrm{~cm}$ in thickness. Two screw holes were then made with a drill. The prepared graft was subsequently installed in the area of the glenoid bone defect. RESUlts: There were no recurrences of the dislocation after the surgical treatment. All patients returned to their previous levels of physical activity. ConCLUSIONS: The proposed method is an alternative to Latarjet procedure and iliac crest bone grafting. The advantages of this method are accurate reconstruction of the bone defect, minimal risk of recurrences, no resorption, and reduction of procedure time.
\end{abstract}

Key words: recurrent shoulder instability, glenoid bone deficiency, Latarjet procedure, surgical treatment, iliac crest bone grafting

Folia Medica 2015; 57(1): 37-42

Copyright (C) 2015 Medical University, Plovdiv

\section{РЕЗЮМЕ}

ВведЕниЕ: Одной из основных причин рецидивирующей нестабильности плечевого сустава является костный дефект переднего края гленоида. Однако существующие методы восстановления костного дефекта имеют некоторые недостатки. ЦЕль: Целью данного исследования явилась разработка метода, который позволит сократить количество послеоперационных осложнений и повысить эффективность хирургического лечения рецидивирующей нестабильности плечевого сустава при костном дефиците гленоида. МАтЕРИАл и Методы: Представлен метод хирургического лечения посттравматической передней нестабильности плечевого сустава с использованием пористого никелида титатана. Мы прооперировали 5 пациентов согласно данной методики. Мы использовали данные компьютерной томографии в предоперационном изготовлении трансплантата из никелида титана. Трансплантат выпиливается из заготовок имеющих цилиндрическую форму толщиной около 1 см. Дрелью формируется два отверстия для винтов. Затем подготовленный трансплантат устанавливают в зону дефекта. Результаты: Рецидивов дислокаций после хирургического лечения зарегистрировано не было. Все пациенты вернулись к прежнему уровню физической активности. Выводы: Метод является альтернативой операции Латарже и восстановлении дефекта с помощью аутотранслантата из гребня подвздошной кости. Преимуществами метода являются точное восстановление костного дефекта, минимальный риск рецидивов, отсутствие резорбции, сокращение времени операции.

Ключевые слова: рецидивирующая нестабильность плеча, костный дефицит гленоида, операция Латарже, оперативное лечение, костная аутотрансплатация

Folia Medica 2015; 57(1): 37-42

(C) 2015 Все права защищены. Медицинский университет, Пловдив

Article's history: Received: 06 February 2015; Received in a revised form: 24 March 2015; Accepted: 27 March 2015

*Correspondence and reprint request to: P. Filipenko, The Sixth Military Hospital of Internal Troops of Internal Affairs Ministry of Russian Federation; Mobile: +7 96184822 95; E-mail: doctorfilipenko@gmail.com

9 Vlasova str., 630075 Novosibirsk, Russia 


\section{INTRODUCTION}

One of the main causes of recurrent anterior shoulder instability is a combination of primary traumatic dislocation with a bone defect of the front edge of glenoid. Bone deficiency is found in $20-30 \%$ of patients who have undergone primary traumatic dislocation $^{1}$, in as much as $90 \%$ of patients with recurrent dislocations, ${ }^{2}$ and in $89 \%$ of cases of unsuccessful surgical stabilization technique of the shoulder ${ }^{3}$. Sugaya et al., using three-dimensional CT in 100 cases of recurrent shoulder instability, found that only $10 \%$ of patients had a normal structure of the glenoid, $50 \%$ had osseous Bankart lesions, and $40 \%$ had varying degrees of osseous erosion. ${ }^{4}$ Among detachable fractures, the majority were classified as medium (5\% to $20 \%$ of the glenoid) or small $(<5 \%$ of the glenoid). Satio at al. found that most of the defects in the front edge of the glenoid were located between 2:30 to $4: 20 .^{5}$

The Bristow-Latarjet procedure is one of the best studied approaches for surgical reconstruction of glenoid bone defects. ${ }^{6,7}$ The major advantages of this procedure include extension of the concavity of the glenoid's bone articular arc (bone effect) and creation of a sling effect of the transferred conjoined tendon (muscle-tendon effect). ${ }^{8}$ Besides, unlike the iliac bone graft, the coracoid bone graft causes no donor-site problems. Therefore, a lower complication rate like bony nonunion is expected with the Latarjet procedure. ${ }^{9}$ But as practice shows, while not disputing the undeniable effectiveness of this method, there are some drawbacks ${ }^{10}$ associated with changes in normal muscle anatomy and surgical trauma of subscapularis, violation of biomechanics and limitation of the external rotation of the shoulder joint, the definite complexity of its implementation, the risk of injury of the brachial plexus and musculocutaneous nerve and a possible development of deforming arthrosis of the shoulder joint.

Another common way to restore a glenoid bone defect is the widespread iliac crest bone grafting (ICBG) currently used in various modifications. ${ }^{11,12}$ However, long-term results of this technique are quite contradictory. The main disadvantages of ICBG are frequent graft resorption, screws migration, additional surgical trauma, and donor-site problems. ${ }^{13,14}$

\section{OBJECTIVE}

The aim of this study was to develop a new method of surgical treatment of recurrent anterior shoulder instability with glenoid bone defect that will allow surgeons to reduce the number of postoperative complications and to improve the efficiency of the surgical procedure

\section{MATERIALS AND METHODS}

To attain this aim in the Department of Endoscopic Surgery of Novosibirsk Research Institute of Traumatology and Orthopedics, we proposed and tested a method of glenoid bone defect reconstruction in chronic recurrent anterior instability of the shoulder using porous titanium nickelide graft. ${ }^{15}$ Absolute indication for using this technique is the presence of significant bone deficiency ( $>25 \%$ of its width) of anterior glenoid part with the formation of 'inverted pear' glenoid. ${ }^{2,3}$ In order to evaluate the effectiveness of the proposed method we selected a group of 5 patients with a long history of recurrent anterior shoulder instability as well as recurrence of instability after other surgical procedures. Indications for surgical treatment were defined by using x-rays, MRI and CT data. Preoperatively, we used multislice computed tomography (MSCT) to evaluate the size and shape of the bone defect in all cases of shoulder instability. Besides glenoid bone defects, different types of capsulolabral injuries and Hill-Sachs lesions were detected. Concomitant injuries were eliminated during arthroscopy. In cases of capsulolabral complex injuries we used a suture anchors fixation technique; in cases of significant osteochondral defects of the humeral head we used the remplissage technique (an arthroscopic infraspinatus tenodesis to fill the humeral head defects). If Hill-Sachs lesions of the humeral head were biomechanically insignificant $(<2 \mathrm{~cm} \text { in length and }<3 \mathrm{~mm} \text { in depth })^{16}$ and not 'engaging' we didn't carry out their plastic. The glenoid bone defect reconstruction was conducted by the method described below.

\section{DESCRIPTION OF THE METHOD}

At the first stage we determine the exact square and shape of the glenoid bone defect. Then using a 3D reconstruction program (Vitrea 2) CT is used to visualize the glenoid with the bone defect in the sagittal plane in the scale of 1:1 (Fig. 1). Next, we use dividers to draw the most appropriate circle (1 in Fig. 1) that fits the rear semicircle of the glenoid cavity. This circle determines the correct anatomical configuration of the glenoid cavity. The shape of the missing part of this circle in the front (anterior-inferior) area of the glenoid corresponds to the shape of the bone defect (2 in Fig. 1). 
It should be noted that modern computer programs for $3 \mathrm{D}$ reconstruction and processing of X-ray data are fairly simple and can be used routinely by any doctor even without special training.

The obtained data are used to make preoperatively the graft from porous titanium nickelide. The graft is sawed from a cylindrically shaped billet about 1 $\mathrm{cm}$ in thickness. Two screw holes are then made using a drill (Fig. 2). The graft surface facing the articular surface should be smooth and curved so that it can fit the curvature of a normal glenoid.

The second stage is the operation. Patients can be positioned either in the lateral decubitus position

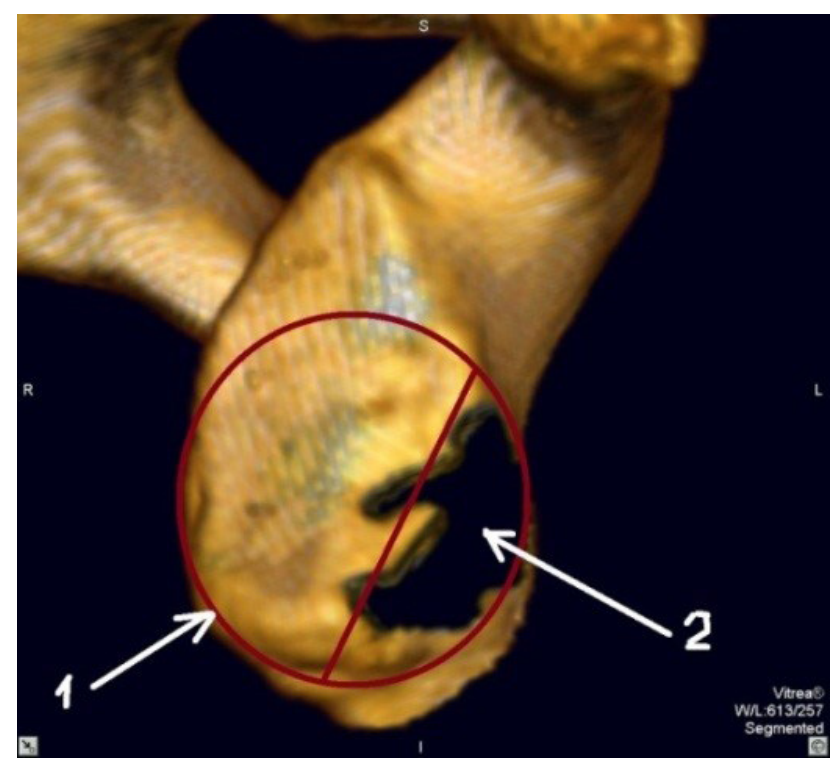

Figure 1. 3D visualization of the glenoid with the bone defect in the sagittal plane.

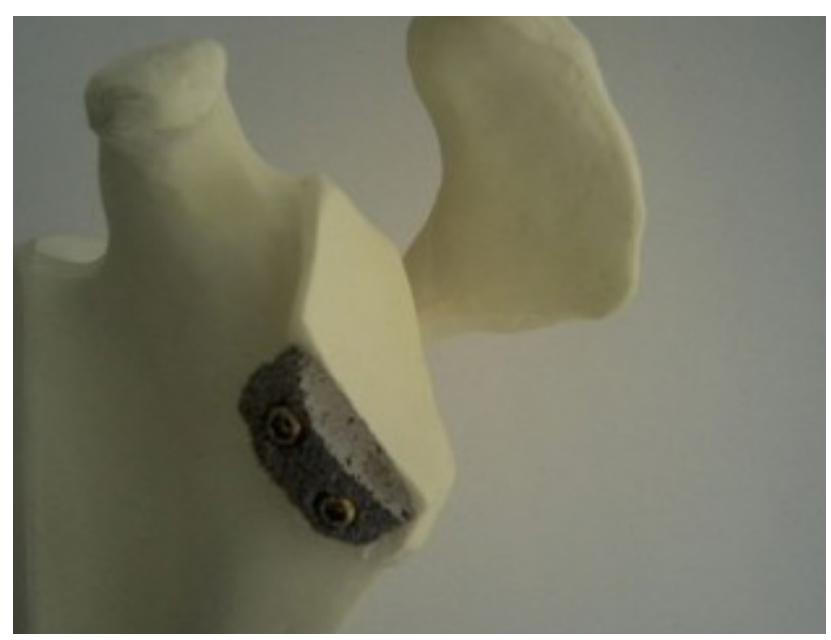

Figure 3. Final fixation of the graft to the edge of glenoid using cannulated screws. with the arm fixed to the distraction device or in the beach chair position. We usually use the lateral decubitus position with the upper limb placed in $30-60^{\circ}$ of abduction and $10-30^{\circ}$ of flexion with traction of $4-5 \mathrm{~kg}$. In aseptic conditions, we use the arthroscopic rear access $(1 \mathrm{~cm}$ below and 1.5 $\mathrm{cm}$ medially to the posterior angle of the scapula acromion process) to provide visualization of the glenoid and the area of the defect. A second portal is placed just above the superior edge of the subscapularis. A cannula is inserted there to facilitate manipulation on the lower aspect of the glenoid. A combination of probes, rasps, motorized shavers and periosteal elevators are used to mobilize soft tissues from the glenoid and prepare the graft bed. Care must be taken not to debride normal tissue needed

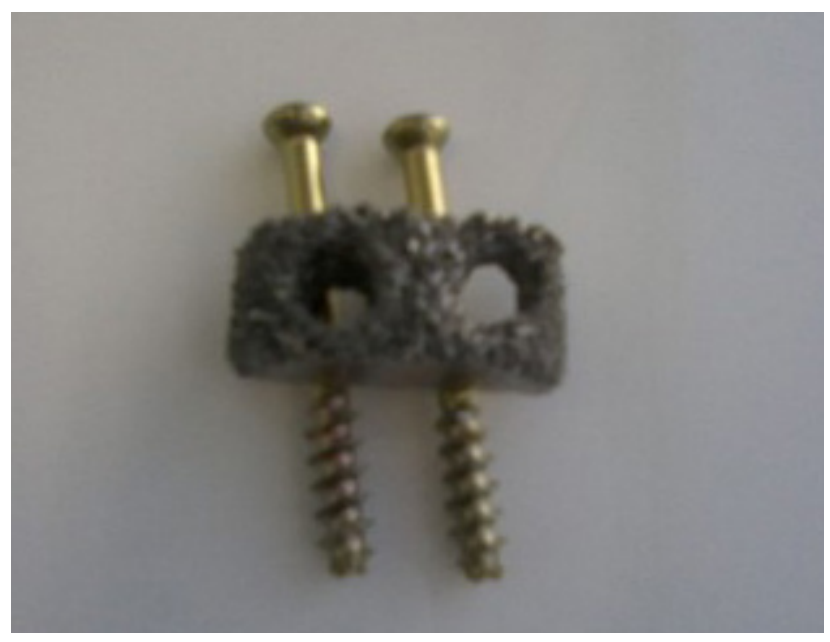

Figure 2. The NiTi graft ready to install.

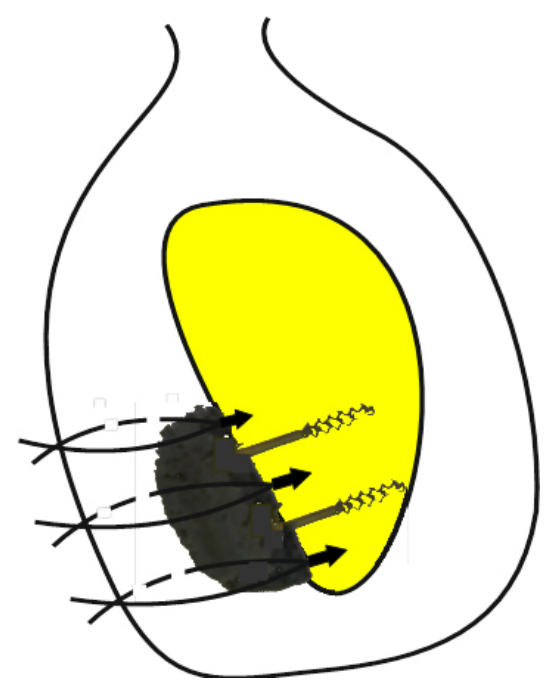

Figure 4. Anchor fixation of capsulolabral complex. 
for the repair. Then we perform a standard (mini) delta-pectoral surgical access. Tendons of coracoidopectoralis and short head of the biceps muscles are displaced laterally or medially. Subscapularis tendon is dissected longitudinally. Arthrotomy is performed. Than we pass Kirschner wire through the area of the bone defect and use it to place the preoperatively modeled graft. Accuracy of setting is controlled visually and arthroscopically. The second wire is threaded through the second hole. Using a cannulated drill we make screw holes and fix the graft by two cannulated screws. Fixation of the graft to the articular process of the scapula is shown on the model (Fig. 3).

Then we suture the capsule and subscapularis muscle with adapting sutures and regain the tightness of the joint. After that we perform arthroscopic fixation of the capsulolabral complex to the front edge of glenoid over the top of the set graft by using suture anchors to cover the graft with soft tissues from a contact with the humeral head (Fig.4).

The operative wound is washed, hemostasis is controlled, and if necessary, drainage is placed. Deltoid muscle and skin are sutured, the upper limb is fixed in a sling for up to 1 month. Then rehabilitation therapy is administered to regain the range of motion in the operated shoulder joint.

\section{AN INTERESTING CASE}

A 31-year-old patient (P.) was admitted to our clinic with a history of recurrent instability in the right shoulder joint. From history: complaints for several

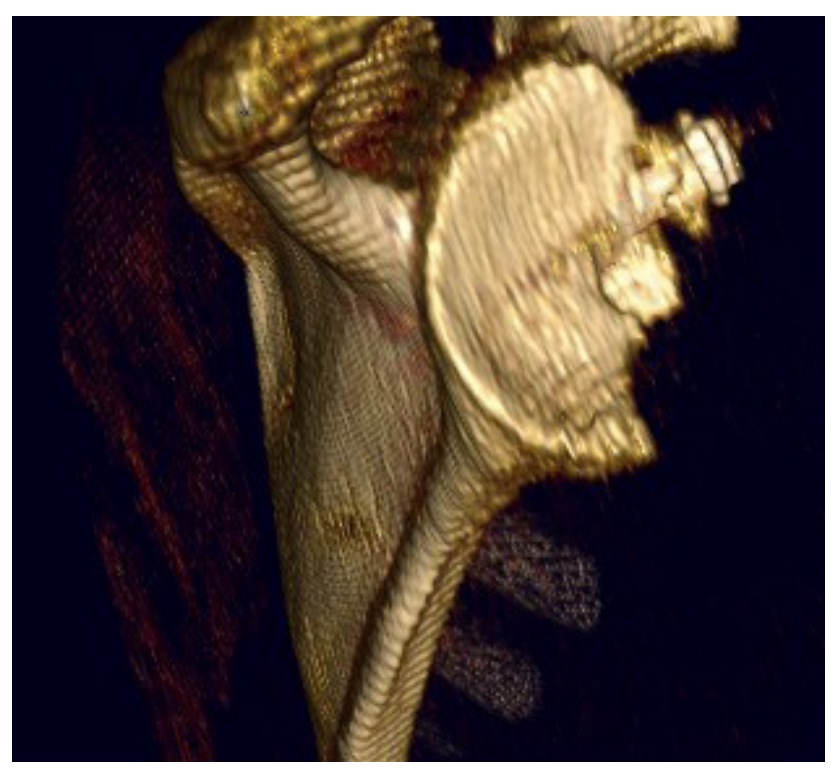

Figure 5. MSCT of patient $\mathrm{P}$. (3D reconstuction of glenoid of scapula) before surgical treatment. years, some years before that he underwent Latarjet procedure with good results, thereafter the patient had a repeated traumatic dislocation of the right shoulder with a fracture of articular process front edge of the scapula. Diagnosis: Post-traumatic recurrent anterior shoulder instability. Bankart-lesions. Stage 2 post-traumatic omarthrosis of the right shoulder joint. Bone defect of an articular process of the scapula. Status - after Latarjet procedure. The computed tomography (Fig. 5) and arthroscopy (Fig. 6) revealed that the glenoid has a bone defect greater than $25 \%$.

The patient received surgical treatment according to proposed method. The graft was implanted in the area of the bone defect as shown in Fig. 7.

The control MSCT (Fig. 8) shows a correct position of the graft, the bone defect is completely replaced, a congruence of the articular surfaces is preserved.

\section{RESULTS}

There were no complications in the short-term postoperative period. The follow up ranged from a few months to 1 year. A Rowe scale ${ }^{17}$ was used to evaluate the results of treatment at 6 months and at one year after surgery. Functional results ranged from 90 to 100 points and were assessed as excellent. The range of motion was restored completely and did not differ from that of the contralateral arm. There were no apprehension symptoms. The objective symptoms of instability were negative. All patients returned to their previous levels of physical activity.

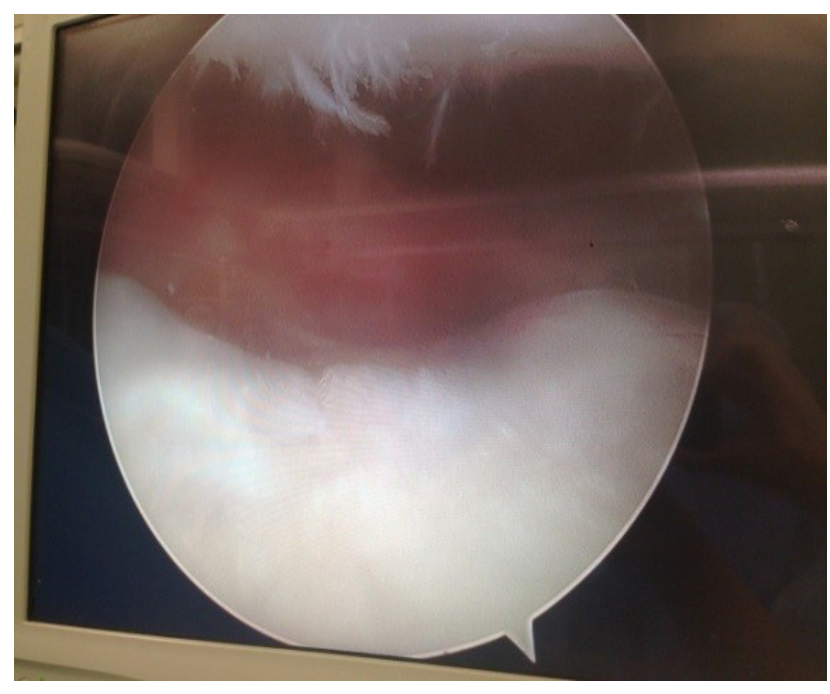

Figure 6. Arthroscopic picture of glenoid defect. 


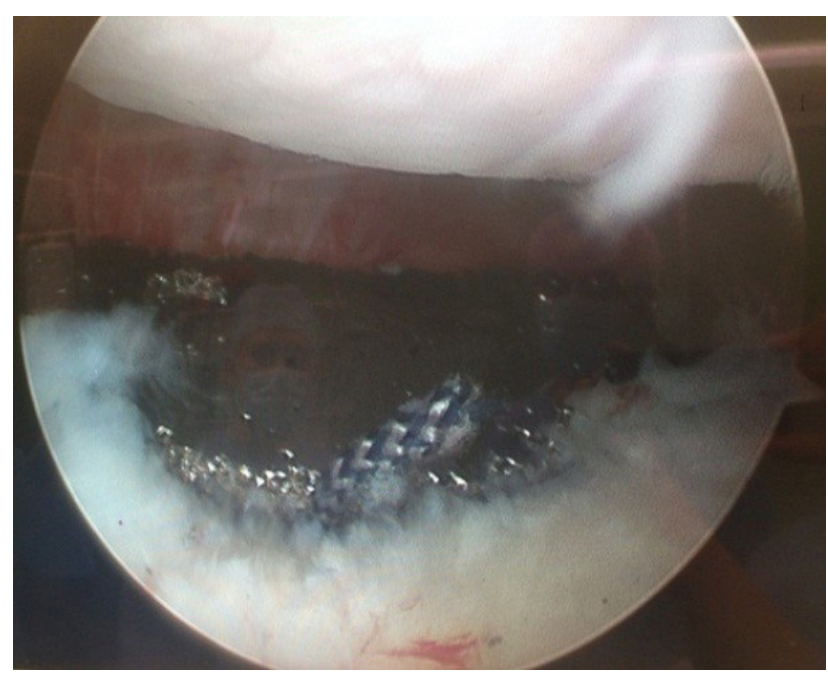

Figure 7. Implanting the graft in the area of the bone defect.

\section{DISCUSSION}

We believe the described technique is noteworthy of practicing surgeons because it has certain advantages and can be applied in cases of long-term recurrent instability with significant bone glenoid deficiency as well as after failing to stabilize the shoulder joint with other operational procedures. Advantages of the proposed method compared to common techniques lies in the fact that this method provides the most complete replacement of the glenoid bone defect with a durable graft which cannot be resorbed. The risk of recurrence of instability is minimized. With careful holding of the preparatory period and graft making of required shape and size the method allows surgeons to restore the correct anatomical shape of the glenoid as accurately as possible and avoid violations of biomechanics and constraints of range of motion in the shoulder joint. Due to biological properties of the material we used, a good consolidation with the bone is produced. ${ }^{15}$ This method does not require additional surgical trauma and eliminates donor-site problems. The time of surgery is reduced.

\section{CONCLUSIONS}

To determine the indications for surgery, particularly in cases of long-term recurrent instability, it is advisable that not only MRI but also computed tomography study be carried out preoperatively. MSCT with 3D visualization allows the surgeon to measure exactly the shape and size of the bone

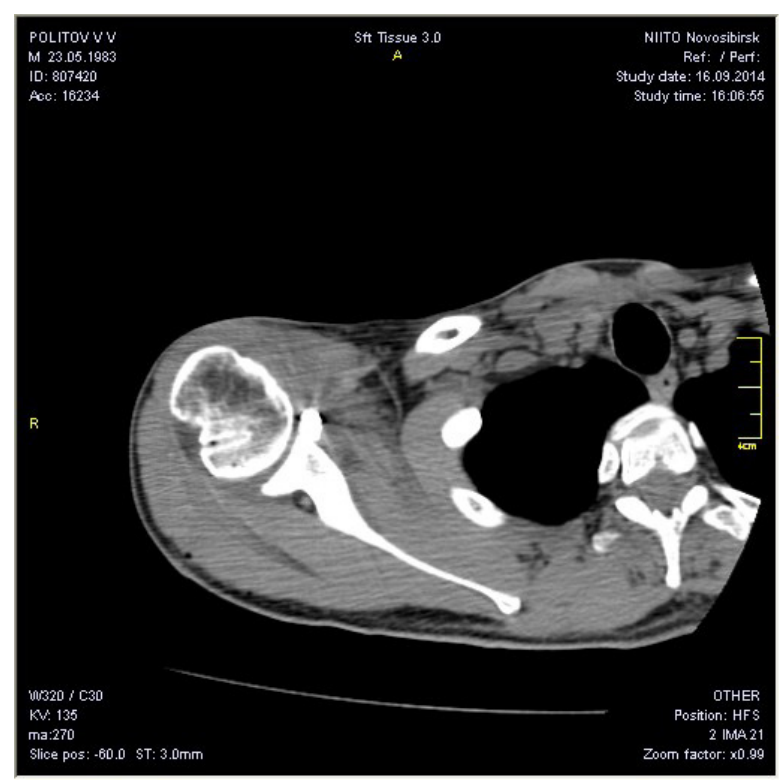

Figure 8. MSCT of patient P. (horizontal plane) after sugical treatment.

defect of the glenoid, which is mandatory if surgery is considered. Using the proposed approach to preoperative planning and surgery minimizes the risks of developing intra- and post-operative complications, enables restoration of the correct anatomical shape of the glenoid and the normal biomechanics of shoulder joint. Thus using modern diagnostics to the full and with thorough preoperative planning we can greatly simplify and improve the surgery efficiency. Further comparative studies are required to make more objective evaluation of the graft consolidation and long-term results assessment of proposed method versus Latarjet procedure and iliac crest bone grafting.

\section{REFERENCES}

1. Taylor DC, Arciero RA. Pathologic changes associated with shoulder dislocations: Arthroscopic and physical examination findings in first-time, traumatic anterior dislocations. Am J Sports Med 1997;25:306-11.

2. Lo IK, Parten PM, Burkhart SS. The inverted pear glenoid: an indicator of significant glenoid bone loss. Arthroscopy 2004;20:169-74.

3. Burkhart SS, De Beer JF. Traumatic glenohumeral bone defects and their relationship to failure of arthroscopic Bankart repairs: Significance of the inverted-pear glenoid and the humeral engaging Hill-Sachs lesion. Arthroscopy 2000;16:677-94.

4. Sugaya H, Moriishi J, Dohi M, Kon Y, Tsuchiya A. Glenoid rim morphology in recurrent anterior glenohumeral instability. Bone Joint Surg Am $2003 ; 85: 878-84$. 
5. Saito H, Itoi E, Sugaya H, Minagawa H, Yamamoto $\mathrm{N}$, Tuoheti Y. Location of the glenoid defect in shoulders with recurrent anterior dislocation. Am J Sports Med 2005;33:889-93.

6. Schroder DT, Provencher MT, Mologne TS, at al. The modified Bristow procedure for anterior shoulder instability: 26-year outcomes in Naval Academy midshipmen. Am J Sports Med 2006;34;778.

7. Allan J, Goutallier D, Glorion C. Long-term results of the Latarjet procedure for the treatment of anterior instability of the shoulder. J Bone Joint Surg Am 1998;80(6):841-52.

8. Patte D, Bernageau J, Bancel P. The anteroinferior vulnerable point of the glenoid rim. In: Bateman JE, Welch RP, Eds. Surgery of the shoulder. New York: Marcel Dekker; 1985:94-9.

9. Hantes ME, Venouziou A, Konstantinos A, et al. Repair of an Anteroinferior Glenoid Defect by the Latarjet Procedure: Quantitative Assessment of the Repair by Computed Tomography. Arthroscopy: The Journal of Arthroscopic and Related Surgery 2010;26(8):1021-6.

10. Auffarth A, Schauer J, Matis N, Kofler B, Hitzl $\mathrm{W}$, Resch $\mathrm{H}$. The J-bone graft for anatomical glenoid reconstruction in recurrent posttraumatic anterior shoulder dislocation. Am J Sports Med 2008;36(4):638-47.
11. Dokolin SY, Kislitsyn MA, Bazarov IS. Arthroscopic Technique of glenoid bony defect autoplasty in patients with recurrent anterior shoulder instability. Traumatology and orthopedics of Russia 2012;3 (65):77-82 (Russian).

12. Monastyrev VV. Surgical treatment of patients with chronic post-traumatic anterior shoulder instability with the bony defect of the articular surface of the blade. Author's abstract of the master's thesis, 2014.

13. Hindmarsh J, Lindberg A. Eden-Hybbinette's operation for recurrent dislocation of the humero-scapular joint. Ada Orthop Scand 1967;38:459-78.

14. Oster A. Recurrent anterior dislocation of the shoulder treated by the Eden-Hybbinette operation: Follow-up on 78 cases. Acta Orthop Scand 1969;40:43-52.

15. Gunther GE, Khodorenko VN, Yasenchuk YF, et al. Titanium Nickelide. Tomsk: MITS press;2006: 23-8.

16. Rowe CR, Zarins B, Ciullo JV. Recurrent anterior dislocation of the shoulder after surgical repair: Apparent causes of failure and treatment. J Bone Joint Surg Am 1984;66(2):159-68.

17. Rowe CR, Patel D, Southmayd WW. The Bankart procedure: a long-term end-result study. J Bone Joint Surg Am 1978;60(1):1-16. 